\title{
Capital Structure and Profitability of Manufacturing Firms listed on the Nigerian Stock Exchange
}

\author{
Gideon Tayo AKINLEYE, LovethOluwatosin AKOMOLAFE \\ Faculty of Management Sciences, Ekiti State University, Ado Ekiti, Nigeria \\ lovethakomolafe@gmail.com
}

\begin{abstract}
This study examined capital structure and profitability of manufacturing firms listed on the Nigerian stock exchange. Specifically the study analyzed the impact of disaggregated variables of debt finance (Short term debt and long term debt) and equity finance (share capital and share premium) on profit after tax. Secondary data were gathered from annual reports of sampled firms over a period of ten years (20082017) and were analyzed using panel data estimators such as pooled OLS estimator, fixed effect estimator, random effect estimator, Hausman test, and Pesaran test of cross sectional dependence. The findings revealed that short term debt has insignificant positive effect on profit after tax of manufacturing firms showing in specific term a coefficient estimate of $0.114985(\mathrm{p}=0.5890>0.05)$ long term debt exerts significant positive impact on profit after tax, with specific coefficient estimate of $0.578290(\mathrm{p}=0.0001<0.05)$ share capital exerts significant positive effect on profit after tax, with coefficient estimate of $0.784525(\mathrm{p}=0.0000<0.05)$ share premium exerts insignificant negative effect on profit after tax, with coefficient estimate of $-0.000395(\mathrm{p}=$ $0.9924>0.05$ ). The study concluded that short term debt has declining effect on the profitability of manufacturing firms in the country, while the long term variable of debt finance of firms spurs the rate of profitability. In clear term disaggregated debt finance subsets exerts significant effect on the profitability of firms sampled in the study. On the other hand equity finance disaggregated into share capital and share premiums reflect that share capital has significant positive effect on profit after tax, while share premium has insignificant negative effect on profit after tax.
\end{abstract}

Keywords: Capital structure, Debt finance, Equity finance, profitability.

\section{Introduction}

It is acknowledged that an organization with a strong capital base may have better returns and value. Although, some commonly believe that a better mix of an organization's capital is the life of any firm. Manufacturing firms no doubt play a significant role in the Nigerian economy because they engage in production of goods for consumption and other needs in the Nigerian economy. Capital structure in manufacturing firms contains long term and short-term debts, retained earnings and equity (Abor (2005). The importance of capital structure to corporate financial stability, growth and adequate returns of manufacturing firms is very important. Capital structure then consists of external and internal sources of financing which includes, long term and short term debts, retained earnings and equity (Akinlo, 2011). Capital structure is the combination or mix of company's equity and debt, which ensures financial stability, profit generation, growth, and expansion. Saad (2010) view capital structure of a company as the precise mix of debt and equity used in financing firm's operations. Profitability is important in determining capital structure. The profitability of a firm depends on a firm's investment opportunities. They are able to invest using the total debt, equity or a combination of debt and equity.

This not only depend on investment expected future cash flows, but also on the cost of these funds. Profitability is one of the indispensable ways for pulling the shareholders to contribute in raising the funds for a firm. Companies with a high level of profitability may have the opportunity to expand or develop their businesses to obtain higher returns (Putrawan, Sinarwati, \& purnamawati 2015). In the past, several empirical studies had been conducted in Nigeria (Aliu, 2012, Adesina, Nwidobie and Adesina, 2015, Chechet and Olayiwola, 2014, Lawal, 2014, Babalola, 2014, Akinyomi, 2013, Aremu, Ekpo, Mustapha, and Adedoyin, 2013, Ogebe, Ogbebe and Alewi, 2013, Shubita \& Alsawalhah, 2012, Osuji and Odita, 2012, Chandrasekharan, 2012, Muritala, 2011, Uremado and Efobi, 2012), in the quest to ascertain what establish the effect of capital structure on organizational profit. Observably only few of these studies concisely focused on manufacturing firms (Babalola, 2013, Akinyomi, 2013, Uremado and Efobi, 2012). However, overview of approach adopted by this study relayed the extent which aggregation had been abused in the dissertation of capital structure. In clear tone, it was observed that most of the studies conducted. In the country on capital structure proxies, debt and equity on aggregation level with attempt. 


\section{Literature Review}

Capital Structure: Capital structure is the mix of debt and equity which makes up firms total capital which is used for its business. Equity is in use means ordinary shares added to retained earnings while debt is taken to mean all fixed interest bearing stock. Gajurel (2005) described capital structure as the "different sources of funds that make up a firm's capital. According to Abor (2008), capital structure is the particular blend of equity and debt and equity a firm uses to finance its operations. Akinsurile (2008) described capital structure as the variables of debts and equity, used by a company to finance its operations, and which usually consist of ordinary share capital, preference share capital and debt capital. The debt and equity combination that maximizes the value of the firm is the firm's optimal capital structure (Ross et al., 2008), and choosing a firm's capital structure remains a crucial strategic choice that corporate managers have to make (Gatsi and Akoto, 2010). To disintegrate element of long term debt from the total debt as well as dissect equity to specifically concentrate on issue share capital and/or share premium. Therefore, this study assessed the effect of capital structure on profitability of manufacturing firms in Nigeria adapting disaggregation approach. long term debt, short term debt, share premium and share capital will be used to proxy capital structure on profitability of quoted manufacturing firms on Nigeria Stock Exchange (NSE). Capital structure decision is important since the profitability of an organization is directly affected by such decision (Kajananthan \& Nimalthasan, 2012).

Equity Finance: Equity is described to be the residual left after subtracting the value of the liabilities of an accounting entity from the value of its assets, where a necessity to return contributed capital and an obligation to distribute the remains itself to particular persons are not counted as liabilities. The company would have more cash on hand for growing business and not obligated to pay back the venture if the company fails but the most difficult part of equity financing is that the company owner might have a hard time to look for the right investor that would agree on every decision the owner might make (Aftab, Ehsan, Naseer, \& Awan, 2012). Also, equity component is the amount of funds left to the shareholders after full settlement of long term debts and short-term debts in the event of liquidation. Arnold (2008) asserts that ordinary shareholders are entitled to receive returns after the claims of preference shareholders and debentures are settled. Shareholders have full rights of information access, direct, and control the company via their votes. Tailab (2014) opines that shareholders (equity holders) are owners of a company and mostly bear the associated risk with the business as they receive residual claims to the resources of the firm.

Debt Finance: Debt financing is the capital that firms raise in the course borrowing funds that is paid at a future period. The good thing about debt financing is that the company relationship ends once the money is paid back and has no more obligations and the interest on the loan is tax deductible. Debt holders are not owners of the business, but creditors that receive a fixed percentage as return on their loan to the company. Interest on debt capital is paid in completely before payment of any dividend to equity holders because the cost of debt (Interest) forms part of the operational cost of a business. Debt financing means borrowing money from third parties and not giving up ownership. That is the financing of business operations through external sources which attracts additional cost known as 'coupon rate' (cost of borrowing). Default to meet this coupon rate may lead to negative consequences to the borrowing firm. The holders of debt capital have an initial claim on firm's assets who bear less risk than shareholders (Myers, 2005)

Empirical Review: Abeywardhana (2015) examined capital structure and profitability an empirical analysis of SMEs in the UK, this study examined the relationship between capital structure and the profitability of nonfinancial SMEs in the Uk for the period of 1998-2008. The researcher used the two stage least squares, (2sls) which showed a significant relationship with capital structure and profitability which is negatively related. The size of the firm appears to have a more important factor that determines the profitability in SMEs in the Uk. There is consistent evidence for positive size- profitability relationship. The results of this study have shown that the capital structure of the firm has a significant influence on the profitability of SMEs in the Uk. Particularly long-term debt to total assets ratio is negatively related with the profitability and this is an indication that SMEs are unenthusiastic to use more equity because of the fear. Samuel (2016) analyzed effect of capital structure on financial performance of commercial banks in Kenya, the grounds of this study was to provide insights into the relationship between capital structure and financial performance of Kenya's banking industry. The board population was the banking industry. Secondary data was used. Data was drawn from a sample of the registered banks by the central bank of Kenya in Kenya. 
The study also used annual reports that were available from their websites and in the central bank of Kenya website. Data was obtained for a ten year period from 2005 to 2014. The finding showed that increase in debt would affect financial performance positively leading to improvement in profitability. If there is an increase in debt levels, the EBIT is expected to increase by $17.6 \%$ per unit measure. Kakanda, Bello and Abba (2016) examined Effect of Capital Structure on Performance of Listed Consumer Goods Companies in Nigeria. The study made use of ex-post facto research design to examine the relationship between independent and dependent variables while controlling for other variables. Descriptive statistics, correlation, and hierarchical multiple regression analyzes were carried out to test the hypotheses developed in the study. Secondary data were sourced from the annual financial reports of the sampled firms from the year 2008 - 2013, which was obtained from African Financial website and official website of Nigerian Stock Exchange. The study found that there is a positive and significant correlation between firm's capital structure and corporate financial performance.

The study specifically found that short-term debt (STD) has no significance positive effect on return on equity (ROE) while Long-term debt (LTD) has positive relation and significant effect on ROE. Foyeke, Olusola and Aderemi (2016), researched on financial structure and the profitability of manufacturing companies in Nigeria. This study employed the use of secondary data. The spearman's rank correlation and regression techniques were used for analysis, using the stats package for a sample of 25 manufacturing companies quoted on the Nigerian stock exchange for the period 2008-2012. The study showed that equity has a significant positive relationship with the profitability of manufacturing companies in Nigeria. The study recommended that managers should improve more facilities on equity capital and policymakers should encourage manufacturing companies to reduce the cost of debt. Siddik, Kabiraj and Joghee (2017) investigated the impacts of capital structure on performance of banks in a developing economy: evidence from Bangladesh. Using panel data of 22 banks for the period of 2005-2014, the study empirically established that capital structure inversely affects bank performance. The findings of this empirical study are of greater significance for the developing countries like Nigeria because it calls for the concentration of the bank management and the policy makers to pursue the policies that reduce reliance on debt to achieve the optimal level of capital structure. The results of this study are also analyzed in the light of earlier studies.

\section{Methodology}

Model Specification: Model used in this study specified profitability measured in terms of profit after tax (PAT) as a function disaggregated capital structure variables include short term debt (STD), long term debt (LTD), share capital (SHC), and share premium (SHP), controlling for firms size (FZ) in terms of natural log of total asset. Function presentation of the model is of given as:

PAT=f (STD, LTD, SHC, SHP, FZ)

Linear representation of the model is presented in the basic forms of panel estimations conducted in the study as:

\section{Where:}

$$
P A T_{i t}=\delta_{0}+\delta_{1} S T D_{i t}+\delta_{2} L T D_{i t}+\delta_{3} S H C_{i t}+\delta_{4} S H P_{i t}+\delta_{5} F Z_{i t}+\mu_{i t}------(3.1)
$$

PAT=Profit after tax

STD $=$ Short Term Debt

LTD=Long Term Debt

SHC $=$ Share Capital

SHP=Share Premium

FZ=firm sized

$\mu_{i t}$ Represent the error term, while $\epsilon_{\mathrm{i}}$ is the random effect term

$\epsilon_{\mathrm{i}}=$ cross sectional effects subsumed into the error term of the random effect model

$\delta_{0}, \delta_{1}, \delta_{2}, \delta_{3}, \delta_{4}, \delta_{5}$ are all parameter estimates of the corresponding models. $\sum_{i=2}^{5} \alpha_{i} D_{i}, \sum_{t=2}^{5} \alpha_{t} D_{t}$ represent sum of differential intercept term across manufacturing firms sampled in the study, with exception of the reference intercept term which is represented by the intercept term.

Source(s) of Data and Method of Analysis: The study focused on five manufacturing firms in Nigeria which include includes Dangote Sugar Refinery, Guinness Nigeria Plc, Nigeria Breweries, PZ Cusson and Unilever Nigeria Plc. Secondary data used in the study were sourced from the Nigerian Stock Exchange fact books, 
annual reports of firms for a period of 10 years, spanning from 2008 to 2017. Data collated were analyzed using correlation analysis, pooled OLS estimator, fixed effect estimator, and random effect estimator, alongside post-estimation tests such as restricted f-test, and Hausman test.

\section{Data Analysis and Interpretation}

Table 1: Correlation Matrix

\begin{tabular}{lllllll}
\hline & PAT & SHC & SHP & STD & LTD & FZ \\
\hline PAT & 1.000000 & & & & & \\
SHC & 0.398046 & 1.000000 & & & & \\
SHP & 0.306715 & 0.230233 & 1.000000 & & & \\
STD & 0.592102 & 0.204151 & 0.375181 & 1.000000 & & \\
LTD & 0.508574 & -0.198209 & 0.302796 & 0.761893 & 1.000000 & \\
FZ & 0.413437 & 0.259793 & 0.593415 & 0.858786 & 0.650268 & 1.000000 \\
\hline
\end{tabular}

Source: Data analysis (2018)

Correlation result presented in table 1 revealed that there is positive correlation between profit after tax, and variables including share capital, short term debt long term debt and firms size. Specifically correlation coefficient reported in table 1 stood at $0.398046,0.306715,0.592102,0.508574$ and 0.413437 for PAT and SHC, PAT and SHP, PAT and STD, PAT and LTD, PAT and FZ respectively. Also, result presented in table 1 reflects there is positive correlation between all pairs of explanatory variables except between SHC and LTD. In particular, reported correlation coefficient stood at 0.230233, 0.204151, $-0.198209,0.259793,0.375181$, 0.302796, 0.593415, 0.761893, 0.858786 and 0.650268 for SHC and SHP, SHC and STD, SHC and LTD, SHC and FZ, SHP and STD, SHP and LTD, SHP and FZ, STD and LTD, STD and FZ, LTD and FZ respectively.

Table 2: Pooled OLS Estimation

\section{Dependent Variable: PAT \\ Method: Panel Least Squares \\ Periods included: 10 \\ Cross-sections included: 5 \\ Total panel (balanced) observations: 50}

\begin{tabular}{ll}
\hline Variable & Coefficient \\
C & -3.872010 \\
SHC & 0.838838 \\
SHP & 0.126179 \\
STD & 1.021167 \\
LTD & 0.590772 \\
FZ & -0.917994 \\
& \\
R-squared & 0.621928 \\
Adjusted R-squared & 0.578965 \\
F-statistic & 14.47596 \\
Prob (F-statistic) & 0.000000 \\
Durbin-Watson stat & 1.040081
\end{tabular}

Source: Data analysis (2018)

Table 2 showed the result of the pooled panel regression output. It was discovered from the result that a linear relationship exists between the capital structure and profitability of manufacturing firms in Nigeria. Specifically, the result showed that share capital exerts significant positive effect on profit after tax with coefficient estimate of $0.838838(\mathrm{p}=0.0001<0.05)$, share premium exerts insignificant positive effect on profit after tax, with coefficient estimate of $0.126179(\mathrm{p}=0.0633>0.05)$, short term debt exerts significant positive effect on profit after tax, with coefficient estimate of $1.021167(\mathrm{p}=0.0113<0.05)$, long term debt exerts significant positive effect on profit after tax, with coefficient estimate of $0.590772(\mathrm{p}=0.0023<0.05)$, while firms size exerts significant negative effect on profit after tax with coefficient estimate of -0.917994 $(\mathrm{p}=0.0012<0.05)$. 
R-squared $\left(\mathrm{R}^{2}\right)$ also known as the coefficient of multiple determination measures the success of the regressions predicts the value of the dependent variable within the sample and tests the goodness of fit. It appears good with the value of $0.621928(62.2 \%)$ which implies that the variables such as share capital (SHC), share premium (SHP), short term debt (STD), long term debt (LTD) and firms size (FZ) have 62.2\% variation in profit after tax (PAT). The results of other statistical tools reveal that the F-test and its probability value are 14.47596 and 0.000000 implying that the independent variables can jointly influence the dependent variable profit after tax (PAT) that is the entire regression test is statistically significant while the adjusted R-square and the Durbin-Watson statistic are considered appropriate in this study at five percent level of significance.

Table 3: Panel Least Square (Fixed Effect Model)

\section{Dependent Variable: PAT}

Method: Panel EGLS (Cross-section weights)

Periods included: 10

Cross-sections included: 5

Total panel (balanced) observations: 50

Linear estimation after one-step weighting matrix

\begin{tabular}{lllll}
\hline Variable & Coefficient & Std. Error & t-Statistic & Prob. \\
C & 31.49928 & 11.78991 & 2.671714 & 0.0109 \\
SHC & -3.942246 & 1.873941 & -2.103719 & 0.0417 \\
SHP & -0.114808 & 0.092695 & -1.238555 & 0.2227 \\
STD & 0.459411 & 0.234780 & 1.956773 & 0.0574 \\
LTD & -0.380626 & 0.262861 & -1.448014 & 0.1554 \\
FZ & 0.046288 & 0.226382 & 0.204468 & 0.8390
\end{tabular}

Effects Specification

Cross-section fixed (dummy variables)

DSR $\quad 0.097630$

GNP $\quad-0.058492$

NB $\quad 0.083249$

PZ CUSSON $\quad-0.088985$

UNP $\quad-0.123403$

R-squared $=0.863624$, Adjusted R-square $=0.832939$, F-statistic $=28.14511$, Prob F-statistic $=0.000$, DurbinWatson stat $=1.483602$

Source: Data analysis (2018)

Table 3 presented shows the result of fixed effect estimation and it revealed that the beta coefficient of constant is positive with the value of 31.49928 and its p-value is 0.0109 indicating that when all the independent variables are held constant, there will be a positive variation up to the tune of 31.49928 units in profit after tax (PAT) and it is significant. However, share capital exerts negative significant impact on profit after tax, with coefficient estimate of $-3.942246(\mathrm{p}=0.0417<0.05)$, share premium exerts negative insignificant impact on profit after tax, with coefficient estimate of $-0.114808(p=0.2227>0.05)$, short term debt exerts insignificant positive impact on profit after tax. With coefficient estimate of 0.459411 $(\mathrm{p}=0.0574>0.05)$ and long term debt exerts insignificant negative impact on profit after tax, with coefficient estimate of $-0.380626(\mathrm{p}=0.1554>0.05)$, while impact of firms size on profit after tax is positive but not significant.

Thorough examinations of the result on the individual selected firms showed that capital structure positively influence the profitability of Dangote Sugar Refinery, Nigeria Breweries by $9.7 \%$, and $8.3 \%$ respectively. However, capital structure under consideration reduced an average profit in Guinness Nigeria Plc, PZ Cusson and Unilever Nigeria Plc by 5.84\%, 8.86\% and 12.3\%respectively in Nigeria. The R-squared (R2) value is 0.863624 that is $86.3 \%$, implying that the independent variables such as share capital (SHC), share premium (SHP), short term debt (STD), long term debt (LTD) and firms size (FZ) have above $86 \%$ variation in the dependent variable profit after tax (PAT). However, the F-statistic value is 28.14511 and its p-value is 0.00000 indicating that the independent variables jointly can impact significantly in profit after tax (PAT). The Durbin-Watson reveals that there is no serial correlation in the variables. 
Table 4: Panel Least Square (Random Effect Model)

Dependent Variable: PAT

Method: Panel EGLS (Cross-section random effects)

Periods included: 10

Cross-sections included: 5

Total panel (balanced) observations: 50

Swamy and Arora estimator of variable variances

\begin{tabular}{lllll}
\hline Variable & Coefficient & Std. Error & t-Statistic & Prob. \\
C & -2.960984 & 1.029169 & -2.877064 & 0.0061 \\
SHC & 0.784525 & 0.138579 & 5.661212 & 0.0000 \\
SHP & -0.000395 & 0.041111 & -0.009604 & 0.9924 \\
STD & 0.114985 & 0.211283 & 0.544223 & 0.5890 \\
LTD & 0.578290 & 0.135815 & 4.257936 & 0.0001 \\
FZ & 0.539312 & 0.287227 & 5.877649 & 0.0141 \\
& Effects Specification & & & \\
\multicolumn{2}{l}{ Cross-section random } & & S.D. & Rho \\
Idiosyncratic random & & 0.279383 & 0.4741 \\
\hline
\end{tabular}

R-squared $=0.519093$, Adjusted R-square $=0.476345$, F-statistic $=12.14328$, Prob F-statistic $=0.000001$, Durbin-Watson stat $=0.747451$

Source: Data analysis (2018)

Random effect estimation result presented in table 4 revealed that share capital exerts significant positive impact on profit after tax, with coefficient estimate of $0.784525(\mathrm{p}=0.0000<0.05)$, share premium exerts insignificant negative effect on profit after tax with coefficient estimate of $-0.000395(\mathrm{p}=0.9924>0.05)$,short term debt exerts insignificant positive effect on profit after tax, with coefficient estimate of 0.114985 ( $p=0.5890>0.05$ ), effect of long term debt is positive and significant, with coefficient estimate of $0.578290(p=0.0001<0.05)$, firms size exerts significant positive impact on profit after tax, with coefficient estimate of $0.539312(\mathrm{p}=0.0141<0.05)$. R-square value reported in table 4.5 stood at 0.519093 , which connotes that about $51 \%$ systematic variation in profit after tax can be explained by short term debt, long term debt, share capital, share premium and firms size. Lastly, the p-value of F statistics is 0.000001 , this implies that the independents variables jointly influence profit after tax (PAT).

Table 5: Hausman Test

Correlated Random Effects - Hausman Test

Equation: Untitled

Test cross-section random effects

\begin{tabular}{llll}
\hline Test Summary & Chi-Sq. Statistic & Chi-Sq. d.f. & Prob. \\
Cross-section random & 7.283035 & 5 & 0.2004 \\
\hline
\end{tabular}

Source: Data analysis (2018)

Table 5 presents the result of Hausman test. Meanwhile, the result shows the chi-square value of 7.28 alongside a probability value of 0.2004 . The result shows that there is no enough evidence to reject the null hypothesis that differences in coefficients of fixed effect estimator and random effect estimation is not significant. It stands that the random effect estimation presented in table 4 is the most suitable estimation for the analysis of the impact capital structure disaggregated into short term debt, long term debt, share capital, share premium and firms size respectively.

\section{Conclusion and Recommendations}

The study concluded that short term debt has declining effect on the profitability of manufacturing firms in Nigeria, while the long term variable of debt finance of firms spurs the rate of profitability. In clear term, disaggregated debt finance subset exerts significant effect of the profitability of firms sampled in the study. On the other hand equity finance disaggregated into share capital and share premiums reflect insignificant 
effect on profit after tax, while only share capital reflecting positive effect, while the effect of share premium is negative. Thus, the result of this study correlates with the studies by Sunday (2015) and Ahmad et al. (2012) that found a positive relation between long-term debt and return on equity. Also, Kakanda, Bello and Abba (2016) in their study on effect of capital structure on performance of listed consumer goods companies in Nigeria affirmed that short-term debt has no significant effect on capital structure, whereas, long-term debt has significant positive effect on the financial performance.

It is also in consensus with Myers and Majluf's (1984) theory, which states that a positive relationship exists between long-term debt and profitability of a firm. Thus, it specifically implies that capital structure has a significant impact on firm's performance. This result is contrary to the one obtained by Abeywardhana (2015) on capital structure and profitability of SMEs in the Uk established a Negative correlation between capital structure and profitability. Also, in the study of Samuel (2016) on the impact of capital structure on profitability of manufacturing industries in Ghana, short-term debt and long-term debt were negatively related to profitability, while equity was positively related to profitability. From these findings, the study recommended that manufacturing firms in the country should restructure their capital structure more to favor long term debt in order to bolster the level of profitability, also the fraction of short term debt should be reduced in the composition of capital structure, so as to minimum the deleterious effect it might pose on the profit prospect of the firms and more attention should be given to share capital than share premium in the make of equity finance of manufacturing firms in the Nigeria.

\section{References}

Ahmad, Z., Abdullah, N. M. H. \& Roslan, S. (2012). Capital structure effect on firms' performance focusing on consumers and industrial sectors on Malaysian firms. International Review of Business Research Papers, 8(5), 137-155.

Abeywardhana, D. K. Y. (2015). Capital structure and profitability: an empirical analysis of SMESs in the UK. Journal of Emerging Issues in Economics, Finance and Banking (JEIEFB), 4(2), 1661-1675.

Abor, J. (2005). The Effect of Capital Structure on Profitability: Empirical Analysis of Listed Firms in Ghana, Journal of Risk Finance, 6(5), 438-45.

Abor, J. (2008). Determinants of the capital structure of Ghanaian firms. African Economic Research Consortium (AERC) Research Paper, 176.

Adedoyin, I. L. (2014). Capital structure and the value of firm: evidence from the Nigeria banking industry. Journal of Accounting and Management, 4(1), 31-41.

Adesina, 0. \& Mwidobie, M. (2015). Capital structure and financial performance in Nigeria. International journal of business and social research, 5(2), 188-195.

Aftab, M., Ehsan, R., Naseer, S. \& Awan, T. (2012). The effect of corporate strategy and capital structure on performance of banking sector of Pakistan. Global Journal of Management and Business Research, 12(17), 67-79.

Agha, H. (2015). Determinants of capital structure of cement sector in Pakistan. European Scientific Journal, 11(13), 353-367.

Akinlo, O. (2011). Determinants of Capital Structure: Evidence from Nigeria Panel Data, African Economic and Business Review, 9(1), 1109-5609.

Akinsurile, O. (2008). Financial Management. Lagos: Eltoda Ventures Ltd. 6th Edition.

Akinyomi, O. J. (2013). Effect of Capital Structure on Firms Performance: Evidence from Nigerian Manufacturing Company. International Journal of Innovative Research and Studies, 2(9), 225-299.

Akinyomi, O. J. \& Olagunju, A. (2013). Determinants of capital structure in Nigeria. Journal of Academic Research in Accounting, Finance and Management Sciences, 2(3), 25-39.

Aliu, N. O. (2012). Effect of Capital Structure on the Performance of Quoted firms, International Journal of Innovation and Applied Studies, 3(4), 999-1005.

Aremu, M. Y., Ekpo, I. C. \& Mustapha, A. M. (2013). Determinants of capital structure in Nigerian banking sector, International Journal of Academic Research in Economics and Management Sciences, 2(4), 2743.

Arnold, J. (2008). Do Corporate Taxes Reduce Productivity and Investment at the Firm Level? Cross Country Evidence from Amadeus Dataset, Working Papers 2008 - 19, CEPII Research center. 
Babalola, Y. A. (2014). Triangulation analysis of capital structure and firms' performance in Nigeria. East Ukrainian National University [(. Dahl] 91034

Babalola, Y. Y. (2013). The effect of firm size on firms' profitability in Nigeria. Journal of Economics and Sustainable Development, 14(5), 90-95.

Chandrasekharan, C. V. (2012). Determinant of capital structure in the Nigerian listed firms. International Journal of Advanced Research in Management and Social Sciences, 1(2), 50-63.

Chechet, I. L. \& Olayiwola, A. B. (2014). Capital Structure and Profitability of Nigerian Quoted Firms: The Agency Cost Theory Perspective. American International Journal of Social Science, 3(1), 139-158.

Cortez, M. A. \& Susanto, S. (2012). Determinants of corporate capital structure: evidence from Japanese manufacturing companies. Journal of International Business Research, 11(3), 121-134.

Foyeke, O. I., Olusola, F. S. \& Aderemi, A. K. (2016). Financial Structure and the Profitability of Manufacturing Companies in Nigeria. Journal of accounting, finance and auditing studies, 2(3), 56-63.

Gajurel, P. D. (2005). Capital structure management in Nepalese enterprises. Master's Degree Thesis, Kathmandu: Faculty of Management, Tribhuvan University.

Gatsi, J. G. \& Akoto, R. K. (2010). Capital structure and profitability in Ghanaian banks.

Kajananthan, R. \& Nimalthasan, P. (2012). Capital structure and its impact on firm performance: a study on Sri Lankan listed manufacturing companies, 1(2), 37-44.

Kakanda, M. M., Bello, A. B. \& Abba, M. (2016). Effect of Capital Structure on Performance of Listed Consumer Goods Companies in Nigeria. Research Journal of Finance and Accounting, 7(8), 211-219.

Kane, K. A., Parrat, J. R. \& Williams, F. M. (1984). An investigation into the characteristics of reperfusioninduced arrhythmias in the anaesthetized rat and their susceptibility to ant arrhythmic agents. $\mathrm{Br}$. J. Pharmacol, 82, 349-357.

Lawal, A. I. (2014). Capital structure and the value of the firm: Evidence from the Nigeria banking industry. Journal of accounting and management Jam, 4(1), 23-44.

Muritala, T. A. (2011). An Empirical Analysis of Capital Structure on Firm's Performance in Nigeria. International Journal of Advances in Management and Economics, 1(5), 116-124.

Myers, S. C. \& Majluf, N. S. (1984). Corporate financing and investment decisions when firms have information that, investors do not have. The Journal of Financial Economics, 13, 187-221.

Myers, S. C. (2005). Determinants of Corporate Borrowing, Journal of Financial Economics, 5(4), 147-175. Ownership Structure, Journal of Financial Economics, 3, 305-360.

Ogebe, J. O., Ogebe, P. 0. \& Alewi, K. (2013). The Impact of Capital Structure on Firms' Performance in Nigeria.http://papers.ssrn.com/sol3/papers.cfm

Osuji, C. C. \& Odita, A. (2012). Impact of capital structure on the financial performance of Nigerian firms. Arabian journal of business and management review, 1(12), 43-51.

Putrawan, P. W., Sinarwati, N. K. \& danPurnamawati, I. G. A. (2015). Pengaruh Investasi Aktiva Tetap, Likuiditas, Solvabilitas, Dan Modal KerjaTerhadapProfitabilitas Perusahaan Otomotif Dan Komponen Yang Terdaftar Di Bursa Efek Indonesia Tahun 2010-2013. E-Journal S1 Ak Universitas Pendidikan Ganesha Jurusan Akuntansi Program S1, 3(1).

Ross, S., Westerfield, R. \& Jaffe, J. (2008). Corporate Finance, 8th Edition, New York McGraw-Hill Irwin.

Saad, N. M. (2010). Corporate governance compliance and the effects of capital structure. International Journal of Economics and Finance, 8, 217-248.

Samuel, D. K. (2016). Effects of Capital Structure on Financial Performance of Commercial Banks In Kenya (The School Of Business And Economics South Eastern Kenya University)

Siddik, N. A., Kabiraj, S. \& Joghee, S. (2017). Impacts of Capital Structure on Performance of Banks in a Developing Economy: Evidence from Bangladesh, International Journal of Financial Studies, 5, 13.

Sunday, I. (2015). Another look at Capital Structure and Corporate Performance in Emerging Markets: The Case of Nigeria. Asian Journal of Business Management, 7(1), 1-12.

Tailab, M. M. K. (2014). The Effect of Capital Structure on Profitability of Energy American Firms, International Journal of Business and Management Invention, 3(12), 54-61.

Uremadu, S. O. \& Efobi, U. R. (2012). The Impact of Capital Structure and Liquidity on Performance: A study on Sri Lankan listed manufacturing companies. Merit Research International Journal of Innovation and Applied Studies, 3(4), 999-1005. 